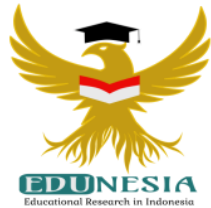

\title{
The Influence of Principal Leadership and Work Motivation on Teaching Quality of Teachers in Ogan Komering Ulu Timur (OKUT) Vocational School
}

\author{
Mensissusanto"; Bukman Lian²; Alhadi Yan Putra ${ }^{3}$ \\ ${ }^{1,2,3}$ Department of Education Management, Universitas PGRI Palembang, Indonesia. \\ ${ }^{1}$ Corresponding Email: mensissusanto76@gmail.com, Phone Number : 0822 xxxx xxxx
}

\section{Article History:}

Received: Dec 29, 2020

Revised: Jan 11, 2021

Accepted: Jan 30, 2021

Online First: Feb 08, 2021

\section{Keywords: \\ Leadership, \\ Principal, Teaching \\ Quality.}

\section{Kata Kunci:}

Kepala Sekolah, Kepemimpinan, Mutu Mengajar.

\section{How to cite:}

Mensissusanto, M., Lian, B. \& Putra, A.Y. (2021). The Influence of Principal Leadership and Work Motivation on Teaching Quality of Teachers in Ogan Komering Ulu Timur (OKUT) Vocational School. Edunesia: Jurnal Ilmiah Pendidikan, 2 (2): 319-332.

This is an open access article under the CC-BY-NC-ND license

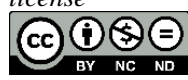

\begin{abstract}
This study aims to determine the influence of principal leadership and work motivation on teaching quality of teachers in Ogan Komering Ulu Timur (OKUT) vocational school. The formulation of the problem in this study: (1) is there an influence of the principal leadership on the quality of teacher teaching?, (2) is there an influence of teacher work motivation on teaching quality?, (3) is there an influence between principal leadership and work motivation on teaching quality of teacher in OKUT vocational school. This study uses a quantitative descriptive method to see the effect partially between the existing variables. The results of this study obtained respondents' perceptions of the principal leadership obtained a score range of 116-150 and an average score of 130.79. Respondents' perceptions of performance motivation on teaching quality of teacher were obtained scores of 107-151 with a total score of 20191.00 and an average score of 134.43. The degree of influence of the principal leadership variable $\left(X_{1}\right)$ and the work motivation variable $\left(\mathrm{X}_{2}\right)$ on teacher's teaching quality $(\mathrm{Y})$ was 0.73 or $73 \%$. Shows that teaching quality of teacher $(\mathrm{Y})$ is jointly (simultaneously) influenced by the principal leadership variable $\left(X_{1}\right)$ and work motivation variable $\left(X_{2}\right)$ by $73 \%$ while the remaining $27 \%$ is influenced by other factors outside the equation model.
\end{abstract}

Abstrak: Penelitian ini bertujuan untuk mengetahui pengaruh kepemimpinan kepala sekolah dan motivasi kerja terhadap mutu mengajar guru SMK Negeri di Ogan Komering Ulu Timur (OKUT). Rumusan masalah dalam penelitian ini: (1) apakah terdapat pengaruh kepemimpinan kepala sekolah terhadap mutu mengajar guru?, (2) apakah terdapat pengaruh motivasi kerja guru terhadap mutu mengajar?, (3) apakah terdapat pengaruh antara kepemimpinan kepala sekolah dan motivasi kerja secara bersama-sama terhadap mutu mengajar guru di sekolah. Penelitian ini menggunakan metode deskriptif kuantitatif untuk melihat pengaruh secara parsial antara variabel yang ada. Hasil penelitian ini didapatkan persepsi responden tentang kepemimpinan kepala sekolah diperoleh rentang skor 116-150 dan skor ratarata 130,79. Persepsi responden tentang motivasi kinerja terhadap mutu mengajar guru di peroleh skor 107-151 dengan jumlah skor 20191,00 dan skor rata-rata 134,43. Derajat pengaruh variabel kepemimpinan kepala sekolah $\left(X_{1}\right)$ dan variabel motivasi Kerja $\left(X_{2}\right)$ terhadap mutu mengajar guru $(Y)$ sebesar 0,73 atau $73,0 \%$. Angka ini menunjukkan bahwa mutu mengajar guru $(\mathrm{Y})$ secara bersama-sama (simultan) dipengaruhi oleh variabel kepemimpinan kepala sekolah $\left(X_{1}\right)$ dan variabel motivasi Kerja $\left(X_{2}\right)$ sebesar $73,0 \%$ sedangkan sisanya $27 \%$ dipengaruhi oleh faktor-faktor lain di luar model persamaan tersebut. 


\section{A. Introduction}

The term leadership isn't a new term for society. In every organization, there is always a leader who runs the organization. To understand the meaning of leadership clearly, it is necessary to examine some of definitions put forward by leadership experts. Leadership is a process of inducing other people to take steps towards a common goal (Locke, 2002). As a first step to studying and understanding everything related to aspects of leadership and its problems (Priansa, 2018). Leadership appears simultaneously with human civilization since ancient times where people gather and work together to defend their existence (Kemal et al, 2019). Since then there has been cooperation between people in the world and the emergence of an element of leadership. Leadership is a behavioral process that becomes a role model for interactions between leaders and followers as well as the achievement of more real goals and mutual commitment in achieving goals and changes to a more advanced organizational culture. Leadership is the process of influencing others in the relationship between leaders and subordinates or with followers. In essence, the meaning of leadership is a process of influencing others to achieve goals in a situation (Rifa'i \& Fadli, 2013).

In simple terms, leadership has a definition, namely the ability that a person has to influence others. This implies that leadership is a person's ability to influence others to comply with all the wishes of the leader (Makawimbang, 2012). The role of the principal is simply defined as a functional teacher who is assigned the task of leading a school where there is interaction between teachers who give lessons and students who receive lessons. According to Lipham (in Priansa, 2018) the principal is responsible for education management, which is directly related to the learning process.

Basically, school management is responsibility of principal and teachers. However, in achieving the success of school management, the participation of parents and students also supports the success. In addition, the achievement of this success must be supported by attitude and ability of the principal in leading educational institutions. The leadership of the principal is expected to create conditions that allow for a harmonious and conducive work climate and human relationships (Kemal \& Hasibuan, 2017). According toWidiatna et al (2020) states that performance is the work results obtained or achieved by a person or group in an organization, in accordance with their respective authorities and responsibilities in order to achieve organizational goals legally, does not violate the lawand according to moral etchics. This explains that school development is very dependent on the leadership of a school principal in managing the school, including developing organizational culture.

Schools function as institutions that provide education and teaching to their students about everything that is not found in the family and further education. The responsibility of the school is very large for the success of the education of its students, both formally, scientifically and functionally. To carry out these responsibilities, there is a joint task between managers of educational institutions, school principals, teachers and students. Likewise with private or state institutions, this responsibility will not be fulfilled if there is no good cooperation with various parties. This means that the success or failure of achieving educational goals in schools depends a lot on the implementation of the learning process which is influenced by educational factors, namely: 1) students, 2) educators, 3) educational objectives, 4) educational tools, and 5) Environment (Sirojudin, 2018).

Educational factors can influence and determine the success of the teaching and learning process in schools. Success is not only determined by the teacher in its implementation, but the learning process must be carried out properly and optimally so that targets can be achieved based on the curriculum. Because it often happens in schools that 
religious teachers like to neglect their duties and responsibilities in teaching, so the class is often empty or students are always told to write a lot or take notes until the time runs out.

This situation indicates a gap in quality of education in schools, namely between schools in city and village. This means that the increase in quality of education in Indonesia is not evenly distributed. The unequal quality of education is caused by three factors as follows: first, the policy and implementation of national education uses the education production function or input-output analysis which is not carried out consequently. second, the implementation of national education is carried out in a centralized manner, thus placing schools as education providers that are highly dependent on bureaucratic decisions that have a very long path and sometimes policies issued are not in accordance with local school conditions. Third, the participation of community, especially parents of students in the implementation of education, has been minimal. (Depdiknas, 2003). Based on that opinion, the dominant factor that causes the unequal quality of education in Indonesia is the inconsistent central government policy accompanied by a centralized implementation of national education with a very long bureaucracy.

The centralistic implementation of education makes regional policies highly dependent on central policies. This has led to demands for educational autonomy. Since the enactment of Law number 22 of 1999 concerning regional autonomy, there have also been changes in the management of national education, namely from centralized to decentralized. The rationale used in response to changes in centralized education management to decentralized are: 1) to place decision-making about schools as close as possible to local conditions, 2) to encourage local innovation and increase the relevance of education to local conditions, 3) so that education actors are more responsible about the implementation of their duties and their quality, 4) to encourage community participation and generate a sense of belonging to the school, especially among parents and the local community, and 5) to encourage stronger local demands including the provision of adequate resources for education (Dikdasmen, 2002).

The rationale for this becomes a solid foundation for implementing autonomy in school management, namely with concrete steps is to implement school management. School management is "the process of making effective and efficient use of human resources for school management which is carried out rationally and systematically so that it can be accounted for to achieve educational goals. Based on this understanding, school leadership becomes a form of management that is carried out independently and puts forward the interests of the school (Bafadal et al, 2020). This means that the principal and teachers are given the authority to regulate and manage the interests of school residents to make their own initiatives based on the aspirations of school residents to improve the quality of education at the school itself, but still in line with the regulations governing the implementation of national education. Therefore the role of the principal and teacher in school management is the initiator, director, and assessor of educational activities (Farida \& Jamilah, 2019). This teacher participates in thinking about planned educational activities. Implementers of educational administration, in addition to being a teacher, are responsible for the smooth running of education and are required to be able to carry out administrative activities (Usman, 2008).

Based on this opinion, in school development, the quality of principal and teacher as the initiator, decision maker, policy maker and implementer of leadership in schools is the principal and teacher. The importance of the leadership of the principal and teachers is to improve the quality of education in school itself. Especially for teachers to improve student achievement for better. This is because teachers, apart from serving as educators, teachers, are also administrators who take care of school administrative matters relating to teacher duties. 
With the leadership of the principal and teacher as feedback or evaluation material for the success of the teaching and learning process as seen from the results of student learning achievement in UASBN.

For this reason, the leadership role of the principal and teachers and teacher work motivation is to improve the quality of teacher teaching to be better than before (Mayasari et al, 2020). For this reason, the leadership of principal and teachers in vocational school must have been applied as a guide in carrying out the teaching and learning process to make it more effective and efficient.

Teacher performance can be seen from their responsibility in carrying out their mandate, profession, and morals (Setiyati, 2014). Then, this is reflected in the compliance, commitment and loyalty in developing potential of students and advancing the school (Priansa, 2018). A teacher has a very strategic role, because its existence is related to the success and quality of education. As a person who is able to translate and describe the values contained in curriculum, then transform these values to students through the learning process in the classroom. Teachers also have various duties related to dedication.

These tasks include the professional field and the humanitarian sector, as well as the social sector (Darmadi, 2015). In the field as a profession, it includes educating, teaching, and training students so that their various potentials are able to develop. Educating means continuing and developing the values of life and life which should be possessed by the participants of the educational ideals to become an important part of the ideal of society. Teaching means continuing the idea of developing knowledge and technology, so that the training participants who are capable of mastering it, means that participants who want to be part of the ideals of society (Priansa, 2018).

The description above explains that teacher performance is the behavior produced by a teacher in carrying out his duties as an educator and teacher when teaching in front of the class, according to certain criteria, namely, planning, implementing, evaluating results, and monitoring the learning process. Thus, the task of a teacher is not only to teach in class, but a teacher also has a great responsibility to educate their students.

\section{B. Method}

This study uses quantitative to see the effect partially between the existing variables (Sugiyono, 2013). The quantitative research variables tested in this study consisted of school principal leadership $\left(X_{1}\right)$ on teacher work motivation $\left(X_{2}\right)$, principal leadership $\left(X_{1}\right)$ on teaching quality of teacher $(\mathrm{Y})$, work motivation $\left(\mathrm{X}_{2}\right)$ on teaching quality of teacher $(\mathrm{Y})$, while testing the hypothesis together (simultaneously), namely the principal leadership $\left(\mathrm{X}_{1}\right)$ and work motivation $\left(\mathrm{X}_{2}\right)$ on teaching quality of teacher $(\mathrm{Y})$, then all data was processed through quantitative analysis.

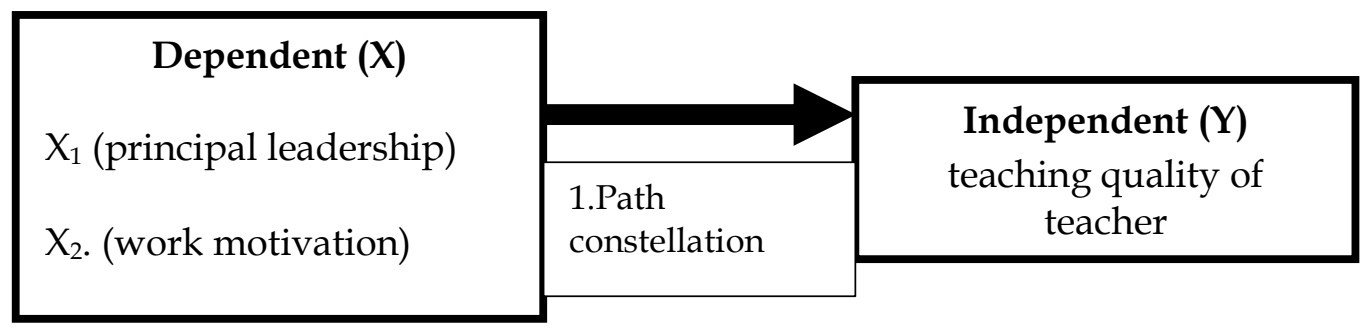

Figure 1. Dependent and independent 
The population in this study were all teachers in OKUT vocational school.

Table 1. Research population

\begin{tabular}{cll}
\hline No & Names of vocational school & Total of teachers \\
\hline 1 & SMK N 1 BP. Bangsa Raja & 35 teachers \\
2 & SMK N 1 Buay Madang & 30 teachers \\
3 & SMK N 1 Bunga Mayang & 33 teachers \\
4 & SMK N 1 Belitang Madang Raya & 35 teachers \\
Total & & $\mathbf{1 3 3}$ teachers \\
\hline Source: & administration of vocational school in OKUT
\end{tabular}

The data collection technique used in this study was a questionnaire. To obtain empirical data about the observed variables, this study uses an instrument in the form of a questionnaire. The questionnaire that will be used to collect data on principal leadership, work motivation and teacher performance will refer to the Likert scale. The Likert scale is a scale used to measure a student attitudes, opinions and perceptions (Riduwan, 2010). By using the Likert scale, the variables to be measured are translated into dimensions, the dimensions are translated again into variables, then the sub variables are translated back into measurable indicators, from this indicator it can be measured to become a starting point for making instrument items in the form of questions that need to be answered by respondents. Each answer is associated with the form of a question or attitude support which is expressed at the following levels:

Table 2. Assessment of instrument items

\begin{tabular}{llc}
\hline No & Alternative Answers & Rating \\
\hline 1 & Always & 5 \\
2 & very often & 4 \\
3 & Often & 3 \\
4 & Seldom & 2 \\
5 & Never & 1 \\
\hline
\end{tabular}

\section{Documentation}

Student learning data achievement is obtained by means of the documentation method. According to Sugihartono (2007) documentation is a way of collecting data by quoting from existing sources of records then the data is used as material for completing one's information. Sources of material for notes can be books, magazines, documents, minutes, and diaries. The documentation method in this study was used to obtain teaching data for teachers at vocational schools in OKUT.

\section{Interview}

According to Hopkins (in Wiraatmadja, 2010) interpreting interviews is a way to find out certain situations in the classroom from the perspective of others. Interviewed persons may include students, the principal, several peers, school administrators, parents of students, and others. The data in the interview is in the form of answers or questions asked. To obtain 
information in interviews, usually a set of questions is asked or arranged in a list. In order for the interview to take place well, in order to obtain the desired data, the researcher or interviewer must be able to create a familiar situation so that there is no distance between the interviewer and the person being interviewed. Interviews with teachers were conducted to obtain initial data about the learning process before conducting research until the final learning process.

\section{Result and Discussion}

The research data is in the form of data descriptions of all variables including principal leadership as variable $\mathrm{X}_{1}$, work motivation as $\mathrm{X}_{2}$, and teaching quality of teacher as variable $\mathrm{Y}$. Research data obtained from 133 respondents for all research variables.

\section{Principal Leadership}

The respondent's perception data about the principal leadership variable was obtained through a questionnaire with 133 respondents in the following table.

Table 3. List of descriptive statistics of principal leadership variables

\begin{tabular}{|lr|r|}
\hline $\mathrm{N}$ & Valid & 133 \\
Mean & Missing & 0 \\
Std. Error of & & 130,79 \\
Mean &, 571 \\
Median & \\
Mode & 130,00 \\
Std. Deviation & 130 \\
Variance & 7,126 \\
Range & 50,774 \\
Minimum & 31 \\
Maximum & 116 \\
Sum & 147 \\
\hline
\end{tabular}

The highest score is 147 , the lowest score is 116 , mean 130.79 , median 130.00 , mode 130 , and standard deviation is 7.126. The categories to find out respondents' perceptions of the principal leadership, namely very bad, not good, good enough, good, and very good, can be seen in the table below:

Table 4. Categories of principal leadership perceptions

\begin{tabular}{clcc}
\hline Score & Category & Frequency & Percentage \\
\hline $116-122$ & Not very good & 10 & 7,51 \\
$123-129$ & Not good & 24 & 18,04 \\
$130-136$ & Good enough & 48 & 36,10 \\
$137-143$ & Good & 31 & 23,30 \\
$144-150$ & Very good & 20 & 15,03 \\
\hline
\end{tabular}


Respondents' perceptions of principal leadership are quite good. The data above can be presented in the form of a bar chart as follows.

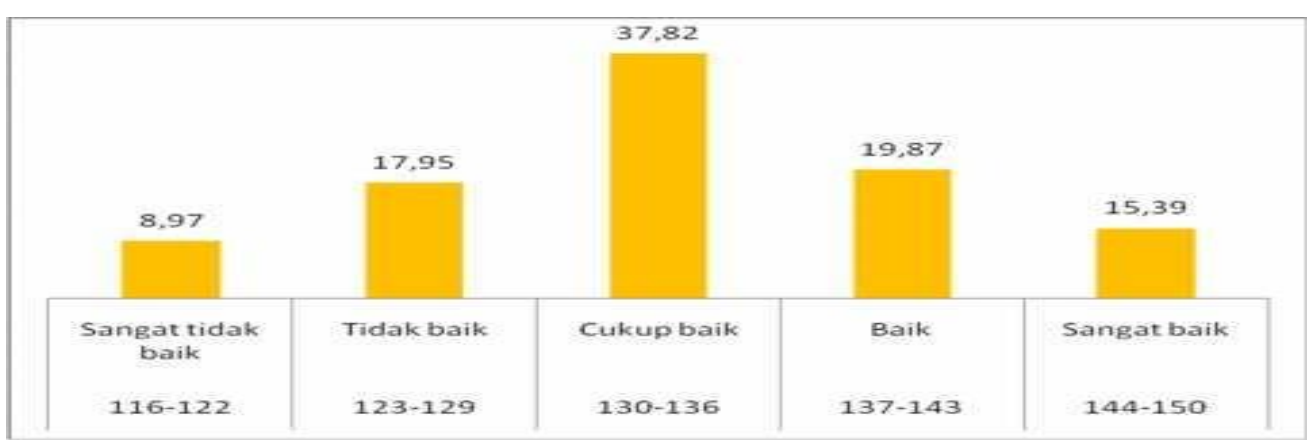

Figure 2. Principal leadership perceptions

The highest result is the score range $130-136$ or $37.82 \%$ indicating that the respondent's perception of the principal leadership is quite good. The lowest was the range $116-122$ or $8.97 \%$ indicating that the respondents' perceptions of the principal's leadership were very bad. Analysis of dimensional factors on the principal leadership variable obtained from the questionnaire is shown in the following table.

Table 5. Analysis of principal leadership variables

\begin{tabular}{|r|r|r|}
\hline \multicolumn{3}{|c|}{ Communalities } \\
\hline X1.1 & \multicolumn{1}{|c|}{ Initial } & Extraction \\
X1.2 & 1,000 &, 695 \\
X1.3 & 1,000 &, 691 \\
X1.4 & 1,000 &, 966 \\
X1.5 & 1,000 &, 372 \\
X1.6 & 1,000 &, 651 \\
X1.7 & 1,000 &, 936 \\
extraction method: principal \\
component analysis.
\end{tabular}

\section{Work Motivation}

The respondent's perception data about the work motivation variable was obtained through a questionnaire with 133 respondents in the following table.

Table 6. List of descriptive statistics of work motivation variables

\begin{tabular}{|ll|r|}
\hline N & Valid & 133 \\
Mean & Missing & 0 \\
Std. Error of Mean & & 134,43 \\
Median & 772 \\
Mode & 129,50 \\
Std. Deviation & 120 \\
Variance & 9,639 \\
& & 92,905
\end{tabular}




\begin{tabular}{|l|r|} 
Range & 43 \\
Minimum & 107 \\
Maximum & 150 \\
Sum & 20191 \\
& \\
\hline
\end{tabular}

The 133 respondents who entered obtained the highest score of 150, the lowest score of 107.00, mean 134.43, median 129.50, mode 120, standard deviation 9.639. The categories to determine respondents' perceptions of work motivation are: very not good, not good, good enough, good, and very good.

Table 7. Categories of work motivation perceptions

\begin{tabular}{clcc}
\hline Score & Category & Frequency & Percentage \\
\hline $107-115$ & Not very good & 11 & 8,3 \\
$116-124$ & Not good & 38 & 28,58 \\
$125-133$ & Good enough & 40 & 30,07 \\
$134-142$ & Good & 35 & 26,31 \\
$143-151$ & Very good & 9 & 6,76 \\
\hline
\end{tabular}

Respondents' perceptions of work motivation are good. The data is in the form of a bar chart as follows.

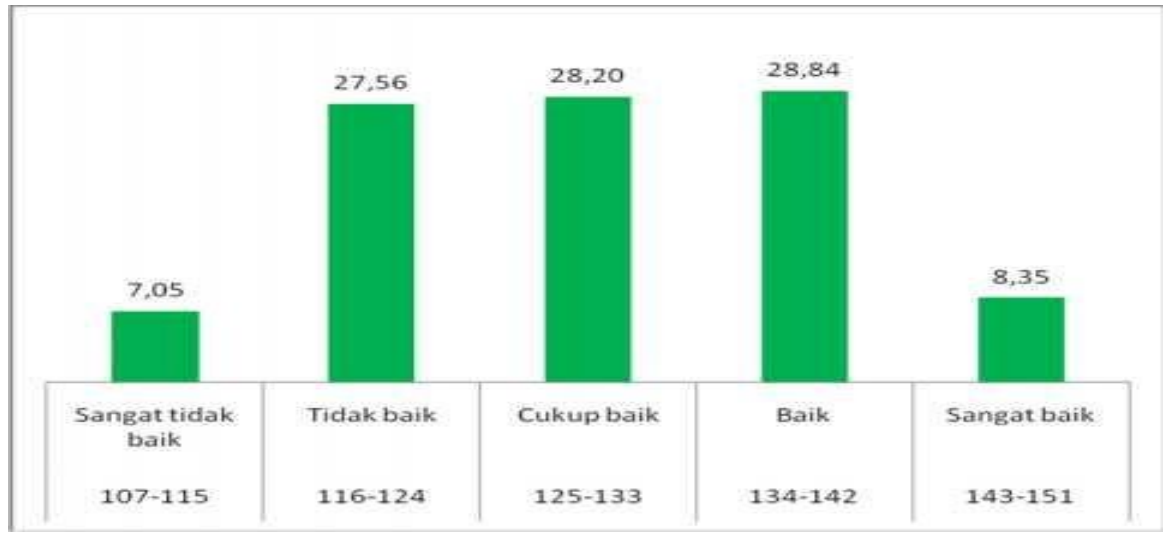

Figure 3. Perceptions of work motivation

The highest result is a score range of $134-142$ or $28.84 \%$ indicating that the respondent's perception of work motivation is good. The lowest was the range $107-115$ or $7.05 \%$ indicating that the respondents' perceptions of work motivation were not very good. Analysis of work motivation variables obtained from respondents' questionnaires is shown in the following table.

Table 8. Analysis of work motivation variables

\begin{tabular}{|r|r|r|}
\hline & Initial & Extraction \\
\hline $\mathrm{X} 2.1$ & 1,000 &, 634 \\
\hline
\end{tabular}




\begin{tabular}{l|l|r|} 
X2.2 & 1,000 &, 727 \\
X2.3 & 1,000 &, 600 \\
X2.4 & 1,000 &, 319 \\
X2.5 & 1,000 &, 532 \\
X2.6 & 1,000 &, 673 \\
X2.7 & 1,000 &, 687 \\
X2.8 & 1,000
\end{tabular} \mid

extraction method: principal component analysis.

The eight dimensions of work motivation variable obtained the highest analysis value for the individual recognition indicator (X2.2) of 0.727 and the lowest for the leader loyalty indicator (X2.4) of 0.319 while for other indicators: advanced opportunities (X2.1) of 0.634, work security $(\mathrm{X} 2.3)$ of 0.600 , job guarantee $(X 2.5)$ of 0.532 , achievement (X2.6) of 0.673 , promotion $(\mathrm{X} 2.7)$ of 0.687 , salary / wages $(\mathrm{X} 2.8)$ of 0.625 .

\section{Teaching quality of teacher}

Data on respondents' perceptions about the teaching quality of teacher are in the following table.

Table 9. Teaching quality of teacher variables

\begin{tabular}{|l|r|}
\hline $\mathrm{N}$ & Valid \\
Missing & 133 \\
Mean & 0 \\
Std. Error of & 53,76 \\
Median &, 368 \\
Mode & 51,00 \\
Std. Deviation & 48 \\
Variance & 4,602 \\
Range & 21,179 \\
Minimum & 19 \\
Maximum & 41 \\
Sum & 60 \\
\hline
\end{tabular}

The highest score was 60 , the lowest score was 41 , the average was 53.76, the median was 51.00, the mode was 48.00, and the standard deviation was 4.602 . The categories for respondents' perceptions of teaching quality of teacher, namely: very bad, not good, good enough, good, and very good, can be seen in the table below.

Table 10. Categories of teaching quality of teacher perceptions

\begin{tabular}{clcc}
\hline Score & Category & Frequency & Percentage \\
\hline $41-44$ & Not very good & 17 & 10,90 \\
$45-48$ & Not good & 42 & 26,92 \\
$49-52$ & Good enough & 39 & 25,00 \\
\hline
\end{tabular}




\begin{tabular}{clcc}
\hline Score & Category & Frequency & Percentage \\
\hline $53-56$ & Good & 43 & 27,56 \\
$57-60$ & Very good & 15 & 9,62 \\
\hline
\end{tabular}

Respondents' perceptions of the teaching quality of teacher are good. Table 10 can be presented in the form of a bar chart below.

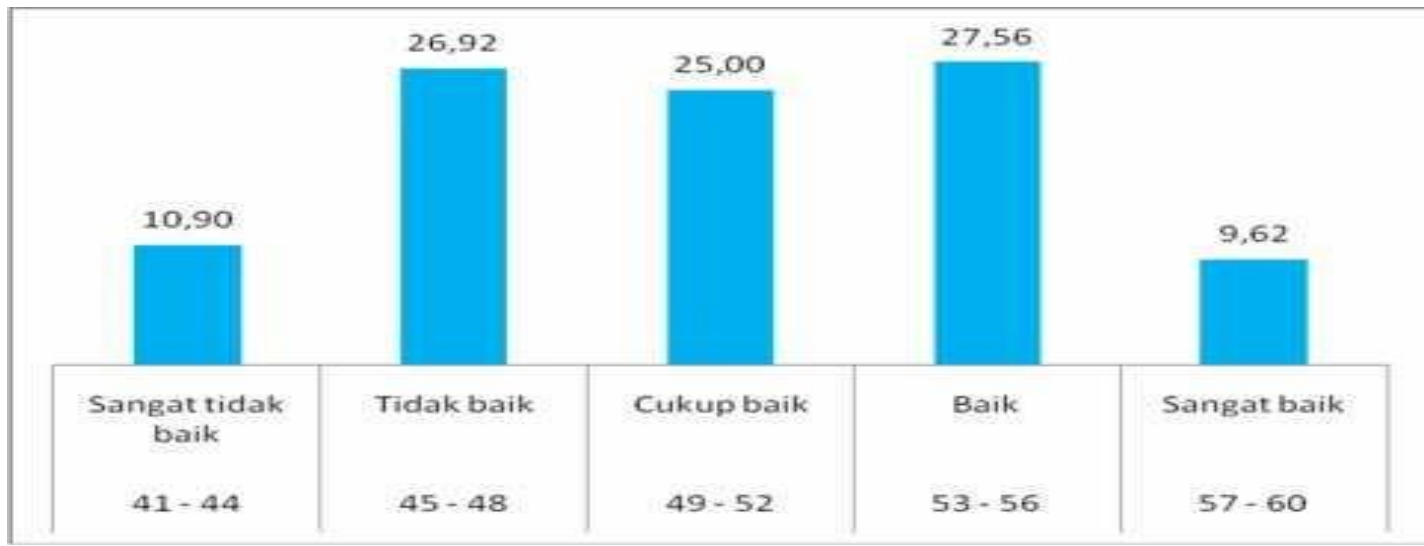

Figure 4. Perceptions of the teaching quality of teacher

The highest result is a score range of $134-142$ or $27.56 \%$ which indicates that the respondent's perception of the teaching quality of teacher is good. The lowest was the range $107-115$ or $10.90 \%$, indicating that respondents' perceptions of the teaching quality of teacher were not very good. Dimensional factor analysis data on teaching quality of teacher variable obtained from the respondent's questionnaire is shown in the following table.

Table 11. Dimensions of the teaching quality of teacher Variables

Communalities

\begin{tabular}{|r|r|r|}
\hline & \multicolumn{1}{|c|}{ Initial } & \multicolumn{1}{|c|}{ Extraction } \\
\hline Y1 & 1,000 &, 739 \\
Y2 & 1,000 &, 675 \\
Y3 & 1,000 &, 710 \\
\hline
\end{tabular}

extraction method: principal component analysis.

The three dimensions of teaching quality of teacher variable obtained the value of factor analysis for the learning planning dimension $\left(\mathrm{Y}_{1}\right)$ of 0.739 , the dimensions of the learning process $\left(\mathrm{Y}_{2}\right)$ of 0.675 , and the dimensions of the assessment $\left(\mathrm{Y}_{3}\right)$ of 0.710 .

Based on the perceptions of respondents, namely the teachers of in vocational school at OKUT about teaching quality of teachers, obtained the score range of 41-60, with total score of 7918 and average score obtained by the respondents was 53.76 which in this case is categorized as good.

The results of analysis factor for the variable teaching quality of teachers obtained the highest average score is the dimension of "learning planning" of 739 . This shows that the teaching quality of teacher seen from the dimensions of learning planning is good, because the 
teacher can prepare a lesson preparation plan well, the teacher able to make annual programs and semester programs well, the teacher has made a good syllabus. While the lowest average score is the dimension of "learning process" of 675 . This shows that the teaching quality of teacher in the learning process is still not optimal, namely in accordance with the learning objectives, providing motivation for students, working with appropriate methods, trategies and carrying out procedures, learning according to plan. The teaching quality of teachers that is good enough will result in student learning achievement which is quite good. Furthermore, the teaching quality of teacher is quite good, seen from the results obtained from the student achievement assessment.

In addition to learning planning, the process of implementing learning, and evaluating learning, the teaching quality of teacher is assessed in implementing the learning process. The learning process is a form of implementing learning that is given by the teacher to students. For that a teacher must have strategies, methods and learning media that are tailored to the learning problems experienced by students.

There are several variables that are thought to have an effect on the teaching quality of teacher, including principal leadership and work motivation. From the research results related to this, the findings are obtained, the results of which we will discuss below.

\section{The Influence of Principal Leadership on Teaching Quality of Quality}

Based on the respondents' perceptions of the principal leadership, the score range is 116-150, with a total score of 20409 and an average score of 130.79 which in this case is categorized as quite good. The seven dimensions of principal leadership include indicators: responsibility, sense of belonging, warmth, support, conflict, appreciation, and commitment. The dimension / indicator that received the lowest score was "support" with a total score of 372. As for the dimension / indicator for "warmth", the highest score was 966 . This can be a concern for the principal of madrasahs / school as a supervisor in order to create leadership for the principal in schools / madrasahs for teachers using the right approach and techniques so that their implementation can run effectively so that they can help teachers to improve the quality of their performance. Furthermore, the principal is expected to have a good warmth in implementing an agenda as a follow-up to creating a school / madrasahs climate so that it can achieve the right goals / targets.

The implication of the results of this study requires that principals who have carried out supervision activities properly so far need to be maintained and even need to be improved / developed possible efforts to further improve the teaching quality of teacher. Based on the findings of this study through regression test, it is known that the influence of the principal leadership on the teaching quality of teacher teaching is $54.3 \%$. This proves that the influence of the principal leadership on the teaching quality of teachers, especially in OKUT vocational school is quite good. Thus it can be explained that the leadership of head of school is able to influence, encourage, guide, direct and mobilize all teachers in order to carry out their duties in managing effective learning.

Based on respondents' perceptions, relevant previous research as well as the findings of this study through regression tests, it can be stated that the principal leadership has a positive and significant effect on the teaching quality of OKUT vocational school teachers can be justified. 


\section{The Influence of Work Motivation on Teaching Quality of Teacher}

Based on respondents' perceptions about the influence of work motivation on teaching quality of teacher, the score ranges from 107 to 151, with a total score of 20191.00 and an average score of 134.43 are in the good category. The eight dimensions of work motivation variable indicators which include: (a) advancement, (b) individual recognition, (c) job security, (d) leadership loyalty, (e) job security, (f) achievement, (g) promotion, (h) salary / wages. Respondents gave the highest score for the dimension of "individual recognition" and the lowest score on the dimension of "leadership loyalty". Thus, it should be the main thing for all teachers to improve the ability of teachers to use learning media tools to improve the quality of learning.

motivation as energy to generate encouragement from within the teacher that influences, arouses, directs and maintains behavior related to the work environment, so motivation from the teacher to fulfill stimulation needs oriented towards individual goals in achieving satisfaction, then implemented to others to provide good service to the community.

The main basis for the implementation of motivation by a leader is knowledge and attention to human behavior that he leads as a determining factor for organizational success that views humans as a determining factor for success which means also according to serious attention to all problems of need (Rizal \& Radiman, 2019). A leader who is successful in carrying out the function of motivation is a leader who has the ability to realize the synchronization between the personal goals of the members of the organization and the personal goals of the members of the organization with the goals of the organization itself.

The results of the findings through regression test that the degree of influence of the work motivation variable on the teacher's teaching quality of Vocational School in OKUT $2015 / 2016$ was 0.732 or $73.2 \%$, the remaining $26.8 \%$ was influenced by other factors.

Based on the respondent's perception of the findings through the regression test in this study, it can be stated that work motivation has a positive and significant effect on the teaching quality of teachers of vocational school in OKUT is correct.

\section{The Influence of Principal Leadership and Work Motivation on Teaching Quality of Teacher}

The degree of influence of the principal leadership variable $\left(\mathrm{X}_{1}\right)$ and work motivation variable $\left(\mathrm{X}_{2}\right)$ on the teacher's teaching quality $(\mathrm{Y})$ was 0.73 or $73.0 \%$. it's shows that teaching quality of teacher $(\mathrm{Y})$ is jointly (simultaneously) influenced by the principal leadership variable $\left(X_{1}\right)$ and work motivation variable $\left(X_{2}\right)$ by $73.0 \%$ while the remaining $27 \%$ is influenced by other factors outside the equation model.

This is in line with the results of Pujiyanti \& Isroah's research entitled, "The Effect of Work Motivation and Work Discipline on Teaching Quality of Teachers of senior high school Ciamis". The results of analysis on this study support the hypothesis, namely work motivation and work discipline together have a positive effect on teacher performance, this is indicated by the value of $R_{\text {count: }} 0.938, F_{\text {count }}: 216.172$, and $R^{2}$ of 0.880 , which means that variations in the increase or decrease in teaching quality of teacher are affected. work motivation variable and work discipline of 0.880 and the remaining $12.0 \%$ influenced by other variables not examined.

Principal leadership created by the principal can be formulated as a series of efforts to provide assistance to teachers in the form of professional services provided by the principal in order to improve the quality of work learning processes and outcomes in addition to the organizational climate, work motivation also has a great influence on teaching quality of 
teacher. Based on the research findings and from previous research, it can be said that there is a positive and significant influence between principal leadership and work motivation together on teaching quality of vocational school in OKUT is correct.

\section{Conclusion}

Based on the results of hypothesis testing regarding the influence of principal leadership on work motivation and its effect on teaching quality of teachers at all vocational school in OKUT, the following conclusions are obtained.

1. The principal leadership of vocational school in OKUT is included in high category but is more effective at task-oriented. The work motivation of vocational school in OKUT is in the sufficient category. And the teaching quality of Vocational School in OKUT is in the sufficient category.

2. Principal leadership has a positive effect on work motivation. This means that the higher the leadership of principal, the higher the work motivation of the vocational school teachers will increase. The amount of increase in principal leadership is the same as an increase in work motivation.

3. Principal leadership has a positive effect on the teaching quality of teachers at vocational. This means that when the principal is leadership, the teaching quality of the teacher will be high, but if the leadership is low, the teaching quality of the teacher will be low.

4. Work motivation has a positive effect on teaching quality of teacher. This means that when the teacher's work motivation is to teach, the teaching quality of teacher will also be high, but if the work motivation is low, the quality of teaching will decrease.

Principal leadership and work motivation have a positive effect on teaching quality of teacher. This means that when the leadership of principal and work motivation at vocational teachers is high, the teaching quality of teachers will be high or increase.

\section{References}

Bafadal, I., Juharyanto, N., \& Ahmad, I.G. (2020). Debat Moral Sebagai Upaya Meningkatkan Integritas Kepala Sekolah. Jurnal Administrasi dan Manajemen Pendidikan, 3 (3), pp. $272-$ 282. http://journal2.um.ac.id/index.php/jamp/article/view/15517

Darmadi, H. (2015). Tugas, Peran, Kompetensi dan Tanggungjawab Menjadi Guru Profesional. Edukasi: Jurnal Pendidikan, 13 (2), pp. 161-174. https://journal.ikippgriptk.ac.id/index.php/edukasi/article/view/113

Depdiknas. (2003). Buku Utama Pengantar Program Pelatihan. Jakarta: Direktorat Sekolah Lanjutan Tingkat Pertama

Dirjen Dikdasmen. (2002). Pelangi Pendidikan Volume 5 No. 2 Tahun 2002. Jakarta: Depdiknas

Farida, S., \& Jamilah, F. (2019). Kepemimpinan Kepala Madrasah (Kompetensi Manajerial Kepala Madrasah Dalam Perspektif Manajemen Pendidikan). Jurnal Ilmu Pendidikan dan $\begin{array}{llll}\text { Ekonomi, } & 4 & (7), & \text { pp. }\end{array}$ https://journal.staidenpasar.ac.id/index.php/wb/article/view/29 
Kemal, I., \& Hasibuan, R.A. (2017). Manajemen Kewirausahaan Melalui Strategi Berbasis Sekolah Di Islamic Solidarity School. Jurnal Akuntabilitas Manajemen Pendidikan, 5 (1), pp. 71-81. https://journal.uny.ac.id/index.php/jamp/article/view/11550

Kemal, I., Suryadi., \& Rosyidi, U. (2019). Management of Lecturers Resource Development at Higher Education. International Journal of Higher Education, 8 (5), pp. 246-256. http://ijhe.sciedupress.com

Locke, E.A. (2002) Esensi Kepemimpinan: Empat Kunci Untuk Memimpin Dengan Penuh Keberhasilan (diterjemahkan dari buku aslinya, The Essence Of Leadership: The Four Keys to Leading Succesfully). Jakarta: Mitra Utama

Makawimbang, J.H. (2012). Kepemimpinan Pendidikan yang Bermutu, Bandung : Alfabeta

Mayasari, L.I., Akbar, M., Eliana., Hardianto, H., \& Kemal, I. (2020). Does Organisational Culture and Creativity Influence Principal's Decision Making?. International Journal of Innovation, Creativity and Change, 14 (2), pp. 625-639. https://ijicc.net/index.php/volume-14-2020/199-vol-14-iss-2

Priansa. D. J. (2018). Kinerja dan Profesionalisme Guru. Bandung: CV Alfabeta

Rifa"I,. \& Fadli, M. (2013). Manajemen Organisasi. Bandung: Cita Pustaka Media Perintis

Rizal, S.M., \& Radiman. Pengaruh Motivasi, Pengawasan dan Kepemimpinan Terhadap Disiplin Kerja Pegawai. Jurnal Ilmiah Magister Manajemen, 2 (1), pp. 117-128. http://jurnal.umsu.ac.id/index.php/MANEGGIO/article/view/3649

Setiyati, S. (2014). Pengaruh Kepemimpinan Kepala Sekolah, Motivasi Kerja, dan Budaya Sekolah Terhadap Kinerja Guru. Jurnal Pendidikan Teknologi dan Kejuruan, 22 (2), pp. 200-207. https://journal.uny.ac.id/index.php/jptk/article/view/8931

Sirojudin, D. (2018). Strategi Sekolah Dalam Pengembangan Pembelajaran Pendidikan Agama Islam. Dinamika: Jurnal Kajian Pendidikan dan Keislaman, 3 (1), pp. 61-86. http:// ejournal.unwaha.ac.id/index.php/dinamika/article/view/228

Sugiyono. (2013). Metode Penelitian Kuantitatif, Kualitatif dan RED. Bandung: CV Alfabeta.

Usman, M.U. (2008). Menjadi Guru Profesional. Bandung: Remaja Rosdakarya.

Widiatna, A.D., Utami, P.P., Herlyna., Ariani, A., Nuryrita, A.S., \& Kemal, I. (2020). Teaching Factory-Based Curriculum Management ( A Case Study At St. Michael Catholic Technical High School Surakarta). Sytematic Reviews in Pharmacy, 11 (12), pp. 1236-1242. http://www.sysrevpharm.org/?mno=11576 